\title{
1. Some historical context
}

\section{Key concepts:}

- The origins of the Bankruptcy Code

- Equity Receiverships

- The Chandler Act

- Chapter 11

Understanding that modern chapter 7 (liquidation) comes from a different heritage than modern chapter 11 (reorganization) can help us understand the very different approaches both take to the basic question of business failure. Because they are now united under a single Bankruptcy Code, these two strands of the law often use common terminology. But their aims and goals are quite different.

The current United States Bankruptcy Code, which includes chapters 7 and 11 among other chapters, was enacted on November 6, 1978, and became applicable to bankruptcy cases commenced on or after October 1, 1979. It has been subject to several amendments since, particularly in 1984, 1994, and 2005.

Bankruptcy cases are presided over by a United States bankruptcy judge, a judicial officer of the local district court. There is a bankruptcy court for each judicial district in the country, and the bankruptcy courts have their own clerks offices and courtrooms. The bankruptcy judges, however, are not appointed by the President. Instead, they are appointed by the judges of the Court of Appeals for the district, for a renewable 14 -year term. ${ }^{1}$

1 Because bankruptcy judges are not appointed under Article III, the scope of their jurisdiction has given rise to a host of complex constitutional issues, that are probably better dealt with as part of a broader consideration of the federal court system. E.g., Wellness Int'l Network, Ltd. v. Sharif, 135 S. Ct. 1932, 191 L. Ed. 2d 911 (2015). 


\section{HOW DID WE GET HERE?}

Article I, Section 8 of the United States Constitution authorizes Congress to enact "uniform Laws on the subject of Bankruptcies."' To the Founders, a single, uniform federal bankruptcy process was preferable to the plethora of state insolvency laws that were enacted both before and after the Revolution. The Bankruptcy Clause can be seen as part of a larger package of provisions - which includes the better-known Commerce Clause - designed to create a national economy. In short, it represents a Hamiltonian vision of the United States.

But until the 1890s, Congress used its bankruptcy power only sporadically. In the nineteenth century, bankruptcy laws would be passed and then repealed in rapid succession. During long periods of time, there was no federal bankruptcy law at all.

In the early days of the Republic, business bankruptcy was the only bankruptcy, because bankruptcy was limited to individual merchants. ${ }^{3}$ In colonial times, and into the years immediately after the Revolution, the English notion that being a gentleman and engaging in business were mutually exclusive largely prevailed. Likewise, legal restrictions kept women out of many professions. Bankruptcy was thus a tool available to a narrow slice of the population - mostly men, who engaged in a specific form of business - and nobody else.

Until at least the 1830s, most business activity was organized in forms that left the entrepreneur fully liable for the debts of the business. Whether sole proprietor or general partnership, the failure of the business also meant the failure of the individual. Because the law provided no discharge for the individual debtor, business failure could mean that the debtor-merchant would be thrown into debtor's prison.

Eventually American bankruptcy law abandoned the English, "merchant only" approach, expanding its coverage to all kinds of debtors. Thus, other business debtors, who might not fit within the narrow definition of "merchant," could now file for bankruptcy. At

2 For more on the Bankruptcy Clause, see Stephen J. Lubben, A New Understanding of the Bankruptcy Clause, 64 CASE W. RES. L. REV. 319 (2013).

3 See Troy A. McKenzie, Bankruptcy and the Future of Aggregate Litigation: The Past as Prologue?, 90 WASH. U. L. REV. 829, 848 (2013). 
the same time, businesses increasingly took on forms that provided for separation between the business and its founders. But it was not until well after the Civil War that corporations could file for bankruptcy, and then the only bankruptcy relief available for indebted companies was liquidation.

Non-bankruptcy law alternatives developed that would avoid the disruption and loss of value associated with liquidation. This was particularly true in the years before 1870 , when a corporate charter was a valuable thing secured from a state legislature No creditor would lightly allow it to lapse in a liquidation or corporate dissolution.

In early days, corporations that found themselves in financial distress would reorganize through the traditional mortgage foreclosure process. In most states, buyers at foreclosure sales could take the corporate charter and start anew, free from old creditors and shareholders. ${ }^{4}$ Some of the old investors would be allowed into the ongoing company, typically in exchange for providing new capital. For example, shareholders might be allowed a diluted stake in the new company, if they agreed to pay an assessment. But it was really all up to the buyers - and if they wanted to leave all the old claimants behind, they could.

Foreclosure worked well in the early days, when the businesses were single-state operations. But a foreclosure sale could not cross

4 Some states still have these statutes on the books. For example, under the New Jersey statutes, the majority of purchasers of certain public service companies (like railroads):

may organize such new corporation by electing a president and board of six directors, to continue in office for one year succeeding such meeting, and annually thereafter, on the same day of the month, a like election for president and six directors shall be held to serve for one year. At such meeting such majority shall adopt a corporate name and corporate seal, determine the amount of the capital stock thereof, and shall have power and authority to make and issue certificates therefor to the persons in interest, to the amount of their respective interests therein, in shares of fifty dollars each.

Such new corporation may then or any time thereafter, create and issue preferred stock to such an amount, and at such times as they may deem necessary, and from time to time issue bonds at a rate of interest not exceeding six per cent per annum, to any amount not exceeding their capital stocks and secure the same by a mortgage of the property, rights, powers, privileges and franchises of such corporation.

N.J. STAT. ANN. § 48:3-24. 
state lines, and once businesses began to grow increasingly complex even when in state, the need for a new mechanism grew. This was particularly the case with regard to railroads, who transformed themselves from local operations into large, multi-state networks during the Gilded Age.

The answer was found in receivers appointed by federal courts. Receiverships have a long history: basically, any court of equity can appoint a receiver to manage property that is the subject of competing claims. When appointed by a federal court, the receiver benefited from broader jurisdiction - extending across the entire district, which might comprise the state - as compared with a state court that frequently exercised jurisdiction only within a single county. Moreover, ancillary receiverships could be commenced in adjoining districts to extend the reach of the receivership wherever the railroad might extend. ${ }^{5}$

The receiver would operate the railroad - sometimes selling debt instruments, known as "receiver certificates," and using the proceeds to fix it up - while the parties negotiated a reorganization plan. Then a foreclosure sale would commence, and the railroad's

5 The process was summarized thusly:

In order to start the reorganization the directors of the road usually persuade some friendly creditor who is a resident of some other state than that in which suit will be started, to file a bill in the Federal court of the district where the railroad was incorporated or where the main office is located. Ancillary receivers are then appointed in all the federal districts where the railroad owns property. Bankers and others interested financially in the reorganization form protective committees to solicit and receive deposits of bonds and stock, and to work with the reorganization managers to effect a plan of reorganization. Bills to foreclose mortgage liens on the properties also are filed. At a sale of these properties the reorganization managers and the protective committees use bonds deposited with the protective committees to buy in the property. Non-assentors to the plan of reorganization must be paid off, in cash usually, together with expenses of the proceeding. The equity court as a matter of policy requires the plan to be submitted to it for approval as a condition to confirming the sale ...

The chief criticisms of these equity proceedings were that they were slow, that the expense has been scandalous, that banker dominated protective committees controlled the proceeding for their own benefit, that after going through the whole proceeding, the financial structure of the railroad in question was often worse off than before.

Charles S. Rhyne, Work of the Interstate Commerce Commission in Railroad Reorganization Proceedings under Section 77 of the Bankruptcy Act, 5 GEO. WASH. L. REV. 749, 753-55 (1937) (footnotes omitted). 
assets would be sold to a new, if similarly named company. For example, the Reading Railroad might become the Reading Railway, with a new capital structure as outlined in the reorganization plan. Dissenters were left behind with claims against the old company.

Thus, when Congress enacted the 1898 Bankruptcy Act, the first permanent federal bankruptcy law in this country, business "bankruptcy" actually encompassed two strands. Companies might be liquidated under the 1898 Act, but an important culture of corporate reorganization had simultaneously developed as part of federal equity jurisprudence. ${ }^{6}$ It was the latter that was utilized in the really large business failures of the day.

Corporate reorganization was federalized - that is, became subject to federal bankruptcy law - in the years of the Great Depression, as the result of a variety of converging forces. First, the Supreme Court was increasingly chipping away at the utility of the receiverships, probably as a result of fears that the process was becoming too controlled by insiders. Receivership courts were also making a lot of law, the law of corporate reorganization, something that did not fit easily with the Court's declaration that there "is no federal general common law."'

At the same time, the need for corporate reorganization exploded during the Depression for obvious reasons. Congress first responded by codifying the receivership process. But then New Deal reformers - most notably, William O. Douglas of the new Securities and Exchange Commission - began investigating the role of Wall Street banks and law firms in receiverships. The many cases in which these big players were seen to dominate proceedings unfairly, at the expense of smaller, retail investors, provided one rationale for a wholesale revamp of the corporate reorganization system.

The result was 1938's Chandler Act, a collection of important amendments to the 1898 Bankruptcy Act. Railroads were allowed to keep their old receivership style provisions under section 77, but all other businesses would have to reorganize under one of two new

6 At this time, railroads were never allowed to liquidate, and could not file under the federal law until the enactment of "section 77" during the New Deal.

7 Erie R. Co. v. Tompkins, 304 U.S. 64, 78 (1938). Congress had the power to legislate on the subject of bankruptcies, under the Bankruptcy Clause, but courts did not. 
chapters. Chapter $\mathrm{X}$ was intended to cover all public companies, and those cases were subject to the oversight of the Securities and Exchange Commission. Big New York banks and law firms were excluded from the process.

Chapter XI was aimed at smaller companies. Under the chapter, the debtor had control over both its own bankruptcy estate and the plan process. In theory secured creditors and shareholders could not have their rights altered by the plan, but they could consent to a modification of their treatment. From 1952 onward, a Chapter XI plan was also not subject to the requirement that it be "fair and equitable," a term the Supreme Court had interpreted to incorporate the "absolute priority rule" from liquidations. ${ }^{8}$ As a result, shareholders could retain stakes in bankrupt companies, even when creditors were not paid in full. ${ }^{9}$

While "although it seems clear that the simplified procedures of Chapter XI were designed for small, privately owned debtors," the chapter was used by many public companies that managed to shoehorn themselves in. ${ }^{10}$ Eventually this convoluted system of three business reorganization provisions (one for railroads and two for other corporations), operating in conjunction with the traditional liquidation bankruptcy provisions, would need to be rehabilitated. And with the enactment of the 1978 Bankruptcy Code, it was.

Under the new Code, all business reorganization was placed in the new chapter 11, the details of which we will encounter in subsequent chapters. The SEC's role was greatly reduced in cases involving public debtors, and "big city" professionals were largely allowed back into the bankruptcy courts. ${ }^{11}$ Suddenly, large law firms had restructuring departments for the first time since the 1930s, and restructuring became an aspect of corporate finance once again.

8 Allocation of Corporate Reorganizations Between Chapters X and XI of the Bankruptcy Act, 69 HARV. L. REV. 352 (1955).

9 See Chapter 17 of this book for more on the absolute priority rule, and its role in a modern setting.

10 Discretion Properly Exercised in Relying on Business Prospects to Allow Chapter XI Arrangement of Large Public Corporate Debtor, 64 COLUM. L. REV. 155, 157 (1964).

11 This was furthered by amendments in 2005 which allowed more Wall Street banks to potentially advise debtors or committees in chapter 11 cases. 
Chapter 7 remained largely as it had been before 1978: a provision for appointing a trustee who would take charge of and sell the bankrupt firm's assets and distribute the proceeds to creditors. Both chapters 7 and 11 reside within the Bankruptcy Code and use a common language as a result. As this brief sketch has made clear, however, they come from very different traditions. And as we will see, sometimes those differences make the common terminology awkward, or even complicated.

Chapter 7 and chapter 11 are both in the current Bankruptcy Code. They both use the same words - but the words have different meanings in many cases.

\section{SUMMARY}

While the Constitution gave Congress the power to enact national bankruptcy laws, Congress only really used that power starting in 1898. Corporate bankruptcy involving liquidations was conducted under that law until it was replaced by the 1978 Bankruptcy Code, the subject of much of this book. But corporate reorganization developed under a receivership process that was only federalized in the 1930s. Later that decade, the Chandler Act made corporate reorganization more transparent, but also more byzantine. The Bankruptcy Code's chapter 11 represents a kind of compromise between the receiverships of old, and the concerns that drove the Chandler Act's reforms. 